\title{
AL-JINSIYYAH AL-MITHLIYYAH PERSPEKTIF OLFA YOUSSEF
}

\author{
Khulaipah Arroudho \\ UIN Sunan Kalijaga Yogyakarta \\ Email. Khulaifaharraudho.@gmail.com
}

\begin{abstract}
The societal construction of sexuality is strongly influenced by ideologically dominated gender relations and paternalistic patriarkhal systems. Generally accepted sexual orientation is heterosexuals, whereas homosexuals are considered to be deviant. Not a few muslims view that homosexuality is a sin and heresy. In this case, Olfa Youssef is responding to homosexuality by saying that alJinsiyyah al-Mithliyyah is not same Liwath of Lut's people. This paper describes the argument of Youssef at the same time criticize it.
\end{abstract}

Abstrak: "Konstruksi sosial masyarakat mengenai seksualitas sangat dipengaruhi oleh hubungan genderyang didominasi ideologi dan sistem patriarkhi paternalistik. Umumnya orientasi seksual yang lazim diterima adalah heteroseksual, sedangkan homoseksual dianggap menyimpang. Tidak sedikit kaum muslim memandang bahwa homoseksualitas merupakan dosa dan bid'ah. Dalam hal ini, Olfa Youssef merespon homoseksualitas dengan mengatakan bahwa al-Jinsiyyah al-Mitsiyyah tidak sama dengan liwath kaum nabi Lut. Tulisan ini memaparkan argumen Youssef sekaligus mengritiknya."

Keywords: Homosexuality, Lut's People, Olfa Youssef, alJinsiyyah al-Mithliyyah 


\section{A. Pendahuluan}

Masalah seksualitas memiliki sebuah sejarah penting yang mampu memengaruhi pandangan manusia mengenai seksualitas. Ia berperan dalam mengubah pemikiran manusia dan kemudian diposisikan sebagai batas antara apa yang dilarang dan apa yang diperbolehkan, antara apa yang benar dan apa yang salah, antara apa yang normal dan apa yang tidak normal, antara apa yang tabu dan tidak. ${ }^{1}$ Seksualitas mendapatkan perhatian khusus dan serius dari Foucalt. Karena baginya, seksualitas adalah masalah-masalah sosial yang dicampuri kekuasaan. Di dalamnya mengandung praktik ketidaksetaraan, penindasan, marginalisasi, gender, politik, eksploitasi dan juga komodifikasi. ${ }^{2}$

Sementaraitu, konstruksisosialmasyarakat mengenaiseksualitas sangat dipengaruhi oleh hubungan gender yang didominasi ideologi dan sistem patriarkhi paternalistik. ${ }^{3}$ Umumnya orientasi seksual yang lazim diterima adalah heteroseksual, sedangkan homoseksual oleh masyarakat dianggap sebagai penyimpangan orientasi seksual. Orientasi seksual disebabkan oleh interaksi yang kompleks antara faktor lingkungan, kognitif dan biologis. Di sebagian besar individu, orientasi seksual terbentuk sejak masa kecil. Hasil penelitian sebelumnya menganggap bahwa ada kombinasi antara faktor biologis dan lingkungan sebagai penyebab orientasi homoseksual. ${ }^{4}$

1 Nanang Martono, Sosiologi Pendidikan Michel Foucalt: Pengetahuan, Kekuasaan, Disiplin, Hukuman dan Seksualitas, (Depok: RajaGrafindo Persada, 2014), 121-122.

2 Masalah-masalah seksualitas yang menyangkut masalah sosial tersebut dituangkan Foucalt di dalam bukunya berjudul The History of Sexuality yang terdiri dari tiga jilid. The History of Sexuality yang pertama membahas perkembangan seksualitas modern, sedangkan The History of Sexuality yang kedua dan ketiga membahas mengenai perkembangan seksualitas masyarakat kuno. Dalam jilid pertama, Foucalt menjelaskan seksualitas dengan memperkenalkan sejarah perjalanan seksualitas sekitar abad 17-an. Ia menjelaskan bahwa pada awalnya seksualitas menjadi konsumsi publik. Namun kemudian kekuasaan kelompok borjuis Victorian mengubah semua aktivitas masyarakat pada masa itu. Adanya kekuasaan yang masuk dalam masalah seksualitas melahirkan masalah-masalah sosial yang lain. Lihat Lisa Downing, The Cambridge Introduction to Michel Foucalt, (United Kingdom: Cambridge University Press, 2010), 126.

3 Musdah Mulia, Islam dan Hak Asasi Manusia; Konsep dan Implementasi, (t.t., Naufan Pustaka, 2010), 287-288.

4 Yogestri Rakhmahappin, “Kecemasan Sosial Kaum Homoseksual Gay dan 
BagibeberapakalanganMuslimmeyakinibahwahomoseksualitas dan transgender adalah masalah dosa dan bid'ah, bukan masalah perbedaan dan keragaman. Menurut Kugle, ketika dihadapkan dengan pembahasan homoseksualitas, para Muslim seringkali tidak memiliki ide yang jelas tentang pengertian homoseksualitas atau hanya menyangkal adanya homoseksual dalam keluarga muslim. ${ }^{5}$ Sementara dari dat a aktual, homoseksualitas merupakan sebuah realita yang nyata. Ada beberapa organisasi Muslim Internasional yang mensupport dan membela para aktivis Lesbi, Gay, Biseksual dan Transgender (LGBT) Muslim. Organisasi-organisasi tersebut konsen di bidang pelayanan dan penanganan kasus-kasus LGBT serta rutin melakukan diskusidiskusi. Organisasi-organisasi tersebut diantaranya adalah al-Fitra Foundation di Afrika Selatan, al-Fatiha Foundation di U.S, Salam Queer Community di Canada, Yoesuf Foundation dan Habibi Ana Foundation di Netherlands. ${ }^{6}$

Dalam ayat-ayat yang memuat kisah kaum nabi Lut pun tidak menyebut secara eksplisit hubungan seksual sesama jenis. Kata dalam Alquran yang sering digunakan untuk merujuk hubungan seksual sesama jenis adalah al-Fahisyah, al-Khabaits, al-Munkar dan asSayyiat. ${ }^{7}$ Ulama fikihpun sepakat seks sesama jenis tidak diterima secara hukum, namun mereka berbeda pendapat soal tingkat hukuman yang akan diberikan. ${ }^{8}$ Kendati sudah berkembangnya beragam pikiran tentang peran gender dan seksualitas dalam Islam, akan tetapi persoalan-persoalan ini masih memerlukan kajian dari sisi Islam yang lebih progressif. Semisal, bagaimanakah yang dimaksud dengan orientasi homoseksualitas? Apakah sama perilaku seksualitas dan orientasi homoseksualitas? Dan seterusnya.

Lesbian”, Jurnal Ilmiah Psikologi Terapan, Vol. II, Januari 2014, 200.

5 Scott Siraj al-Haqq Kugle, Homosexuality in Islam: Critical Reflection on Gay, Lesbian, and Transgender Muslims, (Oxford: One World Publications, 2010), 6.

6 Ibid., 12.

7 Amreen Jamal, "The Story of Lut and the Quran's Perception of the Morality of Same-Sex Sexuality”, Journal of Homosexuality, Vol. 41 (1), tahun 2001.

8 Lihat Abu Abdullah Muhammad ibn Ahmad al-Anshori al-Qurtubi, alJami'Li Ahkam Al-Quran, Jilid IV, (Beirut: Dar al-Kutub al-Ilmiyah, 2010), 155. 
Salah satu tokoh dalam kajian Alquran yang cukup peka terhadap isu gender dan seksualitas serta tanpa henti mengeksplorasi kontradiksi dalam kesimpulan-kesimpulannya tentang teks suci adalah Olfa Youssef. Menurut Youssef, homoseksualitas dewasa ini tidak seperti homoseksualitas yang terjadi pada zaman nabi Lut. Homoseksualitas dewasa ini lebih menyoroti fenomena relasi sesama jenis yang ada di dalam ikatan pernikahan.

Tulisan ini akan membahas argumentasi Olfa Youssef mengenai tafsirnya tentang ayat-ayat al-Jinsiyyah al-Mithliyyah. Dalam usahanya, Youssef menginterpretasikan ayat-ayat tersebut melalui teori-teorikontemporer, dimanahasiltafsirdilihat berbeda.Harapannya implikasi dari metode yang ia gunakan akan relevan untuk menjawab tantangan perubahan sosial terutama terhadap wacana al-jinsiyyah alMithliyyah.

\section{B. Siapakah Olfa Youssef?}

Olfa Youssef (ألفة يوسف) merupakan seorang professor, seorang pemikir dan seorang penulis ternama di Tunisia yang belum banyak dikenal di kalangan akademik Indonesia. Ia dilahirkan di Soussa, Tunisia pada tahun 1964. Pendidikan dasar ia tempuh di al-Mahatta School, lalu melanjutkan sekolah menengahnya di al-Tahir Shafr Institute pada tahun 1983. Ia pernah belajar di Dar Mu'allimin alUlya di Soussa, lulus pada tahun 1987 dengan predikat 'Qarib Min al-Hasan'. Kemudian ia melanjutkan pendidikannya di Universitas Manuba dan meraih gelar Ph.D bidang bahasa Arab dan sastra dari universitas tersebut pada tahun 2002. ${ }^{9}$ Di samping pendidikan formal, ia juga aktif di berbagai seminar-seminar baik seminar nasional maupun seminar di negara-negara Arab lainnya (Mesir, Bahrain, Suriah, Maroko).

Selain karir akademik, aktivitas sosial lainnya diantaranya ia pernah tercat at sebagai guru bantu di sebuah sekolah pada tahun 1989 dan 1992, menjadi dosen pada tahun 2002 pada fakultas Adab, Seni dan Humaniora Universitas Manuba, dan dosen di Sekolah Tinggi Ilmu Bahasa Tunisia semenjak Oktober tahun 2007. Olfah berkesempatan

${ }^{9}$ www.olfa-youssef.prog. Akses tanggal 7 april 2017. 
menjadi Direktur Sekolah Tinggi untuk Pendidikan Anak di Carthage, Persia pada tahun $2003^{10}$, juga pernah menjabat sebagai Direktur Umum perpustakaan nasional Tunisia tahun 2008 dan dikabarkan mengundurkan diri dari jabatannya dengan alasan lingkungan kerja yang tidak kondusif pasca revolusi 2011. ${ }^{11}$

Youssef termasuk penulis pegiat feminis yang produktif khususnya dalam bidang linguistik Arab, psikoanalisis dan Islamic Studies. Di antara karya-karya ${ }^{12}$ berbentuk buku yang ditulis olehnya adalah: (1) Nisa wa Dzakirah. Terbit tahun 1992 di Tunisia. (2) Buhüth fi khitāab al-Sadd al-masraḥī. Terbit tahun 1994 di Tunisia. (3) AlMusajalah Baina Figh wa al-Lisaniyyat Inda Ba'dh al-Lughawiyyin al-Arab al-Mu'ashirin. Diterbitkan berbahasa Arab pada tahun 1997 di Tunisia. (4) Al-Ikhbar 'An al-Mar'ah Fi Al-Qur'an wa al-Sunnah. Diterbitkan dua kali, pertama pada tahun 1997 oleh penerbit Sihr li al-Nasyr, kemudian pada tahun 2009. (5) Ta 'addud al-Ma 'ná fi alQur'ān: Bahth fi Usus Ta 'addud al-Ma 'ná fi al-Lughah min Khilāl Tafāsīr al-Qur'ān. Terbit berbahasa Arab tahun 2003. (6) Nāqisāt 'Aql wa Dīn: Fușül fi Hadith al-Rasūl: Muqārabah Taḥlilìah Nafsīyah. Terbit dua kali dalam bahasa Arab. Pertama pada tahun 2003, dan kedua tahun 2011. (7) Le Coran au Risque de la Psychanalyse. Karya ini dipublikasikan berbahasa Perancis pada tahun 2007 oleh penerbit Albin-Michel. (8) Hayratu Muslimah: fi al-Mirats wa al-Zawaj wa al-Jinsiyyah al-Mithliyyah. Karya ini ditulisnya pada tahun 2008 dan diterbitkan untuk kedua kali pada tahun 2011. Karya ini sudah diterjemahkan ke dalam bahasa Inggris pada tahun 2016 dengan judul The perplexity of a Muslim woman : over inheritance, marriage, and homosexuality. (9) Syauq: Qiraah fi Arkan al-Islam. ${ }^{13}$ Buku ini diterbitkan berbahasa Perancis dan Arab yang dipublikasikan antara tahun 2010-2013, dan (10) Karya terbaru terbit tahun 2016 berjudul Sept Controverses en Islam: Parlons-En!. ${ }^{4}$, berbahasa Perancis yang dipublikasikan oleh French Elyzad, Tunisia.

\footnotetext{
${ }^{10}$ www.olfa-youssef.prog. Akses tanggal 7 april 2017.

11 https://en.wikipedia.org/wiki/Olfa_Youssef. Diakses tanggal 15 Januari 2017.

www.olfa-youssef.prog. Akses tanggal 7 april 2017.

${ }^{13}$ http://www.worldcat.org/. Diakses tanggal 15 Januari 2017.

14 www.africabib.org. Diakses tanggal 03 Spetember 2017.
} 


\section{Makna Al-Jinsiyyah al-Mithliyyah}

Istilah al-Jinsiyyah al-Mithliyyah adalah istilah bahasa Arab yang diambil dari akar kata al-Jinsiyyah yang artinya seks, dan alMatsal yang artinya homo. ${ }^{15}$ Istilah tersebut sering dipakai dalam bukubuku ilmiah yang berasal dari bahasa Inggris. ${ }^{16}$ Secara etimologis, homoseksualitas berasal dari bahasa Yunani, 'homoios' berarti sama, danbahasaLatin 'sexus'berarti jenis kelamin. ${ }^{17}$ Istilah itudiperkenalkan pertama kali oleh Karl Maria Kerbeny, seorang dokter berkebangsaan Jerman-Hongaria pada tahun $1896 .^{18}$

Sedangkan secara terminologi, definisi homoseksual adalah ketertarikan berupa disorientasi pasangan seksual. ${ }^{19}$ Pengertian lain dari homoseksual adalah kecenderungan psikologis dan emosional berupa rasa tertarik secara perasaan (rasa kasih sayang, hubungan emosional), ataupun sosial terhadap orang-orang yang berjenis kelamin sama, dengan atau tanpa hubungan fisik (jasmaniah). ${ }^{20}$

Olfa Youssef sendiri tidak mendefinisikan homoseksualitas secara jami'-mani'. Membicarakan homoseksualitas akan merujuknya pada pembedaan makna kosa kata Sihaq (perempuan menyukai sesama perempuan/lesbi) dan Liwath (lelaki suka terhadap laik-laki/gay).

\section{Pandangan Ulama Mengenai Al-Jinsiyyah al-Mithliyyah}

Pada pendahuluan sebelumnya dikatakan bahwa ulama fikih tradisional sepakat hubungan seks sesama jenis tidak diterima secara hukum, namun berbeda pendapat soal tingkat hukuman yang akan diberikan. Mazhab Maliki menegaskan hukuman rajam kepada pelaku dan sasaran, baik menikah ataupun belum. Sebagaimana

${ }^{15}$ www.almaany.com diakses tanggal 15 Januari 2017.

16 Rama Azhari, Membongkar Rahasia Jaringan Cinta Terlarang Kaum Homoseksual, (Jakarta: Hujjah Press, 2008), 24.

17 Tommy Dwi Pranata, "Perilaku dan Realitas Sosial Kehidupan Gay di Kota Samarinda", e-Journal Sosiatri-Sosiologi, Vol. 3, 2015, 140.

18 Rama Azhari, Membongkar Rahasia..., 24-25.

19 Nietzell, dkk. Abnormal Psychology, (Boston: Allyn \& Bacon, Inc.), 1998, 489.

20 Kendall, P. C., Abnormal Psychology Human Problems Understanding Second Editions, (Boston: Houghton Mifflin Company, 1998), 375. Lihat juga Argyo Demartoto, Mengerti, Memahami dan Menerima Fenomena Homoseksual, (t.t., t.p., 2010), 17. 
riwayat dari mazhab Atha', an-Nakh'iy, Ibnu al-Masib dan yang lainnya mengatakan: "Dirajam jika yang melakukan sudah menikah, dipenjara dan disiplinkan bagi yang belum menikah". Imam Malik merujuk pada dalil QS. Al-Hijr [15]: 74. Pendapat ini juga diamini oleh mazhab Hanbali. Sement ara mazhab Hanafi mengatakan tidak baiknya hukuman fisik. Adapun mazhab Syafi' i berpendapat unt uk menghukum dengan dikiyaskan pada hukum zina. ${ }^{21}$ Hukuman dapat diberlakukan jika ada empat saksi laki-laki yang adil. Dengan demikian, menurut fikih Syafi'i yang terjadi di tempat publiklah yang bisa dihukum. Yang menuduh dengan tanpa bukti juga bisa dihukum. ${ }^{22}$

Satu hadis yang diriwayatkan oleh Abu Daud, Ibnu Majah, Tirmidzi, Nasa'i dan Darul Qutni, dari Rasulullah SAW. berkata: "barang siapa yang mendapati seseorang melakukan perbuatan seperti perbuatan kaum nabi Lut maka bunuhlah yang melakukan dan sasaran"23. Sementara hadis yang disandarkan kepada Abu Bakar ra. mengisahkan: Seorang laki-laki bernama Fuja'ah melakukan perbuatan seperti yang dilakukan kaum nabi Lut divonis untuk dibakar hidup-hidup sesuai pendapat Ali bin Abi Thalib. Ketika itu, ia menulis surat kepada Khalid bin Walid yang kemudian dikirimkan kepada Abu Bakar. Menanggapi surat tersebut, Abu Bakar mengumpulkan sahabat-sahabat Nabi dan bermusyawarah. Dalam suratnya, Ali bin Abi Thalib menulis dan mengemukakan pendapat: " Sesungguhnya perbuatan ini tidak dilakukan seorangpun kecuali pada masa nabi Lut seperti yang kalian tahu. Saya berpendapat untuk membakarnya hidup-hidup". Para sahabat menyepakati pendapat Ali bin Abi Thalib dalam sidang musyawarah dan menuliskan surat jawaban yang dikirim melalui Khalid bin Walid. Lalu hukum tersebut diikuti oleh beberapa pemimpin setelahnya. Diantaranya Ibn Zubair, Hisyam bin Walid dan Khalid al-Qasri di Irak. ${ }^{24}$

${ }^{21}$ Abu Abdullah Muhammad ibn Ahmad al-Anshori al-Qurtubi, al-Jami' Li Ahkam Al-Quran, Jilid 8, (Kairo: Dar al-Kutub al-Mishriyyah, 1964), 155.

22 Mohammad Yasir Alimi, Dekonstruksi Seksualitas Postkolonial, XXVIII.

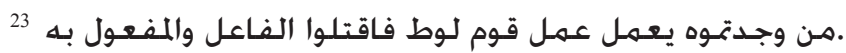

Dalam Abu Daud, Ibnu Majah dan Tirmizi ditambahkan redaksi matan: "menikah ataupun belum menikah".

${ }^{24}$ Abu Abdullah Muhammad ibn Ahmad al-Anshori al-Qurtubi, al-Jami' Li Ahkam Al-Quran, 156. 
Menanggapi tujuan tentang kisah dalam ayat-ayat Alquran, salah satunya adalah bertujuan untuk mengajarkan dan menyajikan persoalan-persoalan moral. Pelajaran yang diajarkan bisa diidentifikasi dengan mengeksplorasi dampaknya kepada generasi pertama umat Islam. ${ }^{25}$ Al-Maraghi misalnya, mengharamkan perilaku homoseksual dengan beberapa alasan: pertama, merusak kaum remaja disebabkan oleh pelampiasan syahwat yang berlebihan. Kedua, merusak para perempuan yang ditinggalkan oleh suami-suami mereka. Ketiga, berkurangnya keturunan karena menyebabkan orang tidak suka terhadap lawan jenis, dan keempat, membuat para suami gemar mendatangi selain tempat 'menanam benih'. ${ }^{26}$

Namun menurut Abdullah Saeed, memperlakukan ayat dalam hirarki nilai tidak semuanya sama. Ayat-ayat yang menurutnya termasuk kategori nilai instruksional memiliki ambiguitas dalam menentukan hukum. Salah satu ayat yang termasuk kategori nilai-nilai instruksional adalah kisah-kisah dalam Alquran. Saeed menetapkan at uran umum untuk menganalisa nilai-nilai instruksional. Diantaranya adalah: (1) semakin sering ayat tersebut disebut di dalam Alquran, semakin besar kemungkinannya untuk diterapkan secara universal; (2) semakin luas cakupan tertentu, semakin besar kemungkinannya untuk diterapkan; (3) semakin umum relevansi dari nilai tertentu, semakin besar kemungkinannya untuk diterapkan; (4) jika nilai itu memenuhi tiga kriteria yang disebutkan, maka nilai tersebut setara dengan nilai universal dan karenanya pemberlakuan bersifat universal dan mengikat; (5) adapun jika nilai itu tidak memenuhi tiga kriteria itu, maka nilai yang dimaksud bukanlah nilai yang bersifat universal (cultural specific) dan pemberlakuannya bergantung pada sitausi dan kondisi. ${ }^{27}$

25 Abdullah Saeed, Interpreting The Qur'an: Towards a Contemporary Approach. terj. Lien Iffah Naf'atu Fina, (Yogyakarta: Baitul Hikmah Press, 2015), 189.

${ }^{26}$ Ahmad Musthofa al-Maraghi, Tafsir al-Maraghi. terj. Bahrun Abu Bakar, Lc. Vol. 8, (Semarang: Toha Putra, 1987), 383.

27 Abdullah Saeed, Interpreting the Quran..., 280. 


\section{E. Tafsir Al-Jinsiyyah al-Mithliyyah Menurut Olfa Youssef}

\section{Al-Jinsiyyah al-Mithliyyah Tidak Sama Dengan Perilaku Liwath Kaum Nabi Lut}

Pandangan homoseksualitas berbasis agama (Islam) merujuk pada teks Alquran berupa kisah kaum Nabi Lut dan sejumlah hadis yang diduga disandarkan langsung kepada Nabi Muhammad. Beberapa kata yang sering digunakan untuk merujuk hubungan seksual sesama jenis adalah al-Fahisyah, al-Khoba'its, al-Munkar dan al-Sayyi 'at.

Menurut Olfa Youssef, hubungan sesama jenis yang terjadi ant ara laki-laki sesama laki-laki mempunyai dua unsur sebab: Pertama, hasrat kepada laki-laki (kodrat). Kedua, hasrat untuk menghindari lawan jenis (perempuan) sebagai suatu yang tidak mutlak, tidak biasa dan di luar dugaan. ${ }^{28}$ Sementara Alquran menjelaskan hubungan tersebut dengan sebab yang kedua, yaitu sebagai unsur di luar dugaan dan tidak mutlak. Artinya, hasrat untuk menghindar tersebut merupakan sikap yang terbentuk karena beberapa faktor, salah satunya adalah faktor sosiokultural maupun lingkungan. ${ }^{29}$

Dengan demikian, apakah Youssef ingin mengatakan bahwa homoseksualitas adalah kodrat atau seperti argumentasinya adalah sebagai perilaku alam bawah sadar? Menurutnya, perilaku liwath sekarang tidak sama dengan perilaku liwath yang terjadi pada masa nabi Lut. Masalah homoseksualitas dewasa ini adalah hubungan sesama jenis yang relasinya ada di dalam ikatan pernikahan. ${ }^{30}$ Sementara hubungan sejenis kaum Lut merupakan perilaku memaksa untuk melakukan hubungan sesama jenis.

Youssef sepakat bahwa liwath merupakan perbuatan fahisyah sebagaimana yang diterangkan di dalam Alquran. Akan tetapi, Liwath

28 Olfa Youssef, Hayrotu Muslimah: fi al-Mi>rats wa al-Zawa $>j$ wa alJinsiyyah al-Mitsliyyah, Cet. III. (Tunisia: Dar al-Sihr li al-Nasyr, 2008), 195.

29 Salah satu penyebab perilaku homoseksual adalah pengaruh sosiokultural maupun lingkungan. Pengaruh faktor sosiokultural misalnya bisa dilihat pada praktik homoseksual masyarakat Melanesia. Sementara faktor lingkungan bisa dilihat pada kalangan santri yang dikenal dengan istilah Mairil dan Sempet. Lihat Deborah A. Elliston, "Erotic Anthropology...", 851; lihat juga Dede Oetomo, Memberi Suara Pada Yang Bisu, 31.

${ }^{30}$ Ibid., 215. 
tidak sama dengan hubungan al-Jinsiyyah al-Mithliyyah dan bukan merupakan hubungan sejenis antara laki-laki. Keterangan tersebut sesuai ayat Alquran QS. Al-Hijr [15]: 68, berbunyi:

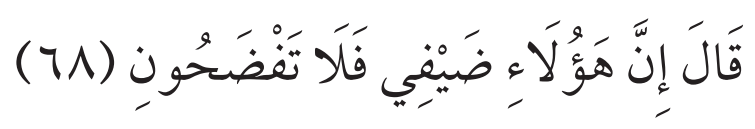

Luth berkata: Sesungguhnya mereka adalah tamuku; maka janganlah kamu memberi malu (kepadaku).

Perilaku liwath kaum nabi Lut berbentuk pemaksaan untuk melakukan perbuatan yang tidak senonoh terhadap tamu-tamu nabi Lut. Bukan hanya itu, mereka berbuat kejahatan yang lain seperti merampok, menjarah, berbuat zalim terhadap makhluk lain. Lalu bagaimana mungkin perbuatan tersebut disamakan dengan hubungan sejenis yang merupakan rasa tertarik dan rasa sama suka (sama-sama ridho).

Menurutnya, homoseksualitas adalah kodrat berdasarkan pemahamannya terhadap teori Lacan tentang struktur ketidaksadaran manusia yang menyerupai bahasa. Lacan menggambarkan hubungan yang sempurna adalah antara laki-laki sebagai subyek pemuas seks yang mempunyai penis sedangkan perempuan sebagai obyek yang menerima. Singkatnya, Lacan menyimpulkan bahwa tidak ada hubungan sesama jenis. Perilaku homoseksualitas dicoba-coba manusia karena tidak puas dengan hasrat dan selalu mencoba hal-hal yang lebih besar. ${ }^{31}$ Sedangkan menurut Youssef, hasrat suka terhadap sesama jenis dalam hubungan adalah pelarian dari kegelisahan dan rasa takut dari hasrat asal manusiawi. ${ }^{32}$

31 Psikoanalisis-struktural Lacan menghasilkan tiga kesimpulan seputar kodrat hasrat. Pertama, hasrat adalah sesuatu yang melampaui biologi. Kedua, jauh dari ego cogito. Ketiga, hasrat dipacu oleh kodrat manusia sebagai makhluk yang berkekurangan secara eksistensial. Kekurangan eksistensial memicu dua jenis hasrat, yaitu hasrat unt uk memiliki dan hasrat unt uk menjadi. Dalam tataran 'yang simbolik', penanda utama adalah pembawa identitas. Identifikasi subyek pada otoritas penanda utama membangkitkan hasrat menjadi obyek 'yang dinginkan' penanda utama tersebut. Identifikasi subjek pada penanda-penanda utama ini mendorongnya untuk menjadi apa yang diinginkan oleh 'lain' yang simbolik. Hasrat untuk diinginkan oleh 'lain' pada gilirannya menuntut hasrat untuk mengidentifikasikan diri dengan 'lain'.

32 Olfa Youssef, Hayrotu Muslimah..., 197. 


\section{Terminologi Sihaq dan Liwath yang Berbeda dalam Alquran}

Dalam merespon homoseksualitas, ulama Islam cenderung menyamakan terminologi sihaq (perempuan menyukai sesama perempuan/lesbi) dan liwath (lelaki menyukai laki-laki/gay). Beberapa kalangan Mufassir menyandarkan isu tersebut kepada kata-kata Fahisyah (فاحشة) seperti dalam QS. An-Nisa [4]: 15 sebagai berikut:

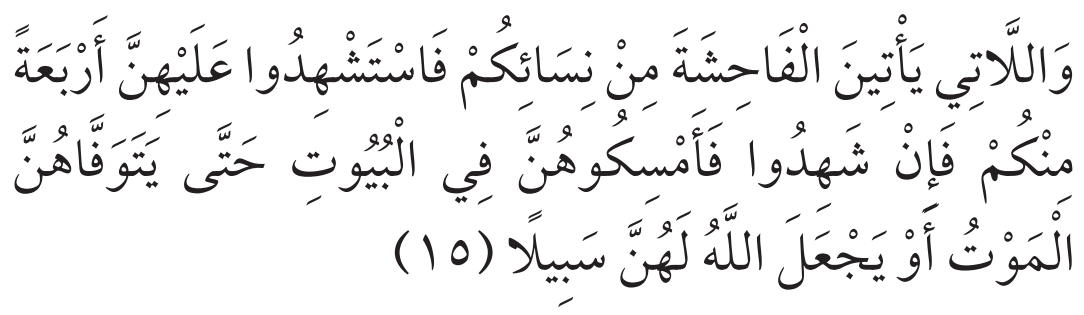

"Dan (terhadap) para wanita yang mengerjakan perbuatan keji, hendaklah ada empat orang saksi diantara kamu (yang menyaksikannya). Kemudian apabila mereka telah memberi persaksian, maka kurunglah mereka (wanita-wanita itu) dalam rumah sampai mereka menemui ajalnya, atau sampai Allah memberi jalan lain kepadanya"

Kata Fahisyah (فاحشة) di dalam ayat di atas merupakan kata yang bersifat umum yang memiliki arti sebagai perbuatan-perbuatan apapun yang tidak menyenangkan jiwa dan perbuatan itu sangat buruk jika diucapkan, hingga lidah tidak mampu untuk mengucapkannya. ${ }^{33}$ Karena keumuman makna lafadz inilah menurut Youssef tidak serta merta menjadikan ayat di atas sebagai landasan untuk menghukumi sihaq.

Makna zina dan homoseks dalam kata الفاحشة tidak mengandung pengertian Isytirak Ma'na Nisbiy. Isytirak Ma'na Nisby dipahami sebagai kata yang memiliki makna lebih dari satu atau kesamaan lafal/ tulisan yang mengandung makna berbeda-beda. Keumuman lafadz tidak bisa dihukumi dan menunjuk pada satu maksud tertentu. Ada beberapa perbuatan sangat buruk yang digambarkan Alquran dengan kata الفاحشة. Dalam QS. Al-Nisa [4]: 19, الفاحشة adalah nusyuz, membangkang perintah suami, menyakiti suami dan keluarganya, dan

${ }^{33}$ Olfa Youssef, Hayrotu Muslimah..., 172. 
lain sebagainya. ${ }^{34}$ Artinya, kata الفاحشـ tidak hanya sebatas perbuatan zina, tetapi mengandung lebih banyak maksud.

Sementara itu, perempuan tidak pernah dijadikan sebagai mukhatab langsung dalam ayat-ayat Alquran. Masalah khusus perempuan sekalipun akan disampaikan melalui mukhatab lakilaki, sehingga senantiasa menjadi paradigma kuat dalam masyarakat bahwa perempuan merupakan makhluk inferior dan subjek pasangan kesenangan kaum laki-laki. ${ }^{35}$ Asumsi itu didukung dengan tidak adanya masalah-masalah perempuan dalam Alquran yang tidak berhubungan dengan laki-laki, seperti pernikahan, thalaq dan 'Iddah diatur sedemikian rupa oleh Alquran sebagai permasalahan yang penting. Demikian halnya dengan haid yang hanya dialami perempuan sebagai sesuatu yang kotor dan diperintahkan untuk tidak mendekati mereka hingga masa suci. Masalah-masalah khusus bagi perempuan hanya diterangkan di dalam sunnah Nabi (hadis) seperti batasan aurat perempuan dalam sholat, larangan sholat dan puasa bagi perempuan haid dan sebagainya.

Menurut Youssef, redaksi ayat-ayat yang menceritakan kisah kaum nabi Lut menyebutkan kata فاحشة untuk menggambarkan perilaku mereka yang mendatangi laki-laki. Namun, kata فاحشة merupakan kata yang bersifat umum yang memiliki arti sebagai perbuatan-perbuatan apapun yang tidak menyenangkan bagi jiwa dan perbuatan itu sangat buruk jika diucapkan, hingga lidah tidak mampu untuk mengucapkannya. ${ }^{36}$ Jumhur mufassir menafsirkan perbuatan adalah perbuatan zina. Sedangkan menurut pendapat yang lain فاحشة adalah segala perbuatan mesum seperti zina, homoseks dan yang sejenisnya.

Selain ayat di atas, ayat lain yang menjelaskan sihaq merujuk pada QS. Ali Imran [3]: 14 untuk melihat paradigma pembaca kontemporer. Kata الناس dalam redaksi ayat masih mengandung makna umum dan luas. Kata الناس dalam kamus bahasa Arab tidak menunjuk pada jenis tertentu atau golongan tertentu. Berbeda halnya dengan

\footnotetext{
${ }^{34}$ Olfa Youssef, Hayrotu Muslimah..., 207-208.

35 Ibid., 173.

${ }^{36}$ Olfa Youssef, Hayrotu Muslimah..., 172.
} 
kata قوم di mana kata tersebut menunjuk pada jenis kelamin laki-laki. ${ }^{37}$ Sehingga secara umum ayat di atas mengandung makna: "Dijadikan indah pada (pandangan) manusia (baik laki-laki maupun perempuan) kecintaan kepada apa-apayang diingini, Yaitu:permepuan-perempuan, anak-anak, harta yang banyak dari jenis emas...".

Ketiadaan pembahasan mengenai Sihaq di dalam Alquran melahirkan kritik sekaligus menuduh perilaku Sihaq sebagai perilaku menyimpang. Ketiadaan isu tersebut menjadi paradoks sekaligus rumit. Secara tidak langsung, sihaq menjadi kritik dan dianggap tidak signifikan di dalam Alquran serta tidak termasuk di dalam peraturan perundang-undangan. Segala sesuatu yang tidak penting bagi lakilaki dianggap tidak penting bagi manusia. Karena adanya manusia dinilai dari sudut pandang laki-laki. Alasan lain karena sihaq tidak memengaruhi at uran sosial masyarakat yang berlaku sebagai pelindung nasab. Sementara argumen lain menuduhkan sihaq dengan menilai sebagai perilaku buruk yang menjijikkan dan tidak sedap dipandang.

Youssef mengingatkan kembali paradoks antara kritik dan tuduhan terhadap perilaku lesbi dengan melihat sisi lain, yaitu imajinasi masyarakat yang menganggap bahwa perempuan sebagai makhluk yang kurang. Apakah artinya paradoks tersebut mengkritik perilaku sihaq dan mempertimbangkannya sebagai alasan apologetik atau malah mengingkarinya? Sementara, isu lesbi tidak dikemukakan secara eksplisit dan tidak ditemukan dalil khusus dalam menyikapinya.

Menurut Youssef ada pendapat yang mengutip ayat QS. AnNisa [4]: 15 untuk melihat masalah ini. Ayat tersebut menekankan kata فاحشة yang menunjuk musahaqat (para lesbian). Meskipun begitu, Alquran mendiamkan isu sihaq dan menyamakan persoalannya dengan isu Liwath. ${ }^{38}$

\section{F. Kritik Analisis Penafsiran Olfa Youssef}

Upaya Olfa Youssef dalam menafsirkan ayat-ayat al-Jinsiyyah al-Mithliyyah bertujuan untuk memberikan gambaran yang berbeda

37 Pengertian itu dikuatkan dengan ayat Alquran dalam surat al-Hujurat [49]:11. Olfah Youssef, Hairotu Muslimah..., 177.

${ }^{38}$ Ibid., 172 
bagi para penentu hukum tentang fenomena hubungan sesama jenis belakangan ini. Penentuan hukum terhadap perilaku seksual butuh penelitian yang lebih mendalam supaya tidak menjadikan hukuman berat sebelah. Sayangnya, Youssef tidak menjelaskan lebih jauh ketetapan batasan-batasan perilaku homoseksual.

Ada kesan tidak tegas dan tidak konsisten apakah homoseksual adalah kodrat atau konstruksi manusia? Apakah yang dikomentari Olfa Youssef adalah orientasi seksual atau perilaku homoseksual? Jika yang dimaksud adalah bagian dari orientasi, maka implikasinya tidak begitu signifikan. Namun jika yang dimaksudkan adalah perilaku, pandangannya membentuk kesan 'mengamini' perilaku homoseksualitas di dalam Islam.

Selain itu, homoseksualitas merupakan permasalahan yang holistik. Ia bisa saja terjadi melalui proses biologis, pengalaman masa kanak-kanak dan pengaruh psikologis. Sedangkan konstruksi perspektifnormatif-teologis, perilakuhomoseksualitas adalah perilaku yang keji, perilaku menuruti hawa nafsu yang dilarang. Dalam QS. AlA'raf [7]: 81 mengatakan bahwa kaum Lut mendatangi laki-laki untuk melepaskan nafsu (Syahwah). Menurut Shahrur sebagaimana dikutip oleh Abdul Mustaqim, ada perbedaan yang cukup mendasar antara gharizah dan syahwah. Gharizah merupakan insting/bawaan sejak lahir, tidak melalui proses belajar, sementara syahwah dipengaruhi oleh faktor pembelajaran dari lingkungan sosial. Jika demikian, maka perilaku homoseksualitas adalah nurture (proses pembelajaran dari lingkungan), tidak nature (alami). ${ }^{39}$

Perdebatan dalam penentuan hukum isu homoseksualitas di dalam Islam setidaknya mempunyai enam argumen: Pertama, pertanyaan mengenai mengapaAllahmenghukum pelakuhomoseksual, sedangkan orientasi tersebut diciptakan?; Kedua, beberapa penelitian ilmiah membuktikan bahwa beberapa gen memengaruhi orientasi seksual. Penelitian dari American Psychiatric Association (APA) menghapuskan homoseksual dari daftar penyakit mental sehingga

${ }^{39}$ Abdul Mustaqim, "Homoseksual Dalam Perspektif Alquran: Pendekatan Tafsir Kontekstual al-Maqashidi", SUHUF: Jurnal Kemenag, Vol. 9, No. 1, Juni 2016, 52-53 
homoseksual bukan merupakan penyakit mental; Ketiga, perdebatan mengenai kata 'homoseksualitas' yang tidak diungkapkan secara eksplisit di dalam Alquran dan beranggapan bahwa kata tersebut hanyalah interpretasi dari Mufasir; Keempat, perilaku yang mengundang azab Tuhan dalam cerita kaum Lut bukan hanya perilaku homoseksual, melainkan perilaku-perilaku keji yang lain termasuk menajrah, berbuat zalim, menghina dan sebagainya; Kelima, hadishadis yang bercerita mengenai homoseksualitas dinilai lemah; dan keenam, orientasi tersebut adalah kebutuhan (necessity) dan Allah memberikan pengecualian untuk kebutuhan. ${ }^{40}$

\section{G. Kesimpulan}

Dari uraian di atas dapat disimpulkan beberapa hal: Pertama, Olfa Youssef berpendapat bahwa al-Jinsiyyah al-Mithliyyah tidak sama dengan perilaku liwath kaum nabi Lut. Jika pergaulan pada masa kaum Lut adalah perilaku yang tidak senonoh, sementara hubungan sejenis dewasa ini merupakan rasa tertarik dan rasa sama suka (samasama ridho).

Kedua, terminologi yang berbeda antara sihaq dan liwath mengaburkan pandangan tentang hukum homoseksualitas. Satu sisi Youssef berpendapat seolah homoseksualitas merupakan orientasi seksual yang sah, di sisi lain ia memperlihatkan ketidaktegasan dalam berpendapat, semisal kesepakatannya terhadap perbuatan yang dilakukan kaum Lut adalah perbuatan sodomi yang dilarang. Atau, mungkinkah jika seseorang mempunyai orientasi seksual tertentu memengaruhi tindak laku seksualitasnya? Wallah A'lam bi asShowab.

${ }^{40}$ Mohamed Yacoub, “Mooting Homosexuality in Islam”, 2. 


\section{Daftar Pustaka}

Alimi, Mohammad Yasir. Dekonstruksi Seksualitas Postkolonial, XXVIII.

Al-Maraghi, Ahmad Mustofa. Tafsir al-Maraghi. terj. Bahrun Abu Bakar, Lc. Vol. 8, Semarang: Toha Putra, 1987.

Al-Qurtubi, Abu Abdullah Muhammad ibn Ahmad al-Anshori. AlJami' Li Ahkam Al-Quran, Jilid IV, Beirut: Dar al-Kutub alIlmiyah, 2010.

Al-Jami' Li Ahkam Al-Quran, Jilid VIII, Beirut: Dar al-Kutub al-Ilmiyah, 2010.

Azhari, Rama. Membongkar Rahasia Jaringan Cinta Terlarang Kaum Homoseksual, Jakarta: Hujjah Press, 2008.

Demartoto, Argyo. Mengerti, Memahami dan Menerima Fenomena Homoseksual, t.t., t.p., 2010. Diakses tanggal 15 Januari 2017. http://argyo.staff.uns.ac.id/files/2010/08/seksualitas-undip.pdf.

Downing, Lisa. The Cambridge Introduction to Michel Foucalt, United Kingdom: Cambridge University Press, 2010.

Elliston, Deborah A. "Erotic Anthropology: "Ritual Homosexuality" in Melanesia and Beyond", Jurnal American Ethnologist, vol. 22, No. IV, 1995.

http://www.worldcat.org/

https://en.wikipedia.org/wiki/Olfa Youssef

Jamal, Amreen. "The Story of Lut and the Quran's Perception of the Morality of Same-Sex Sexuality", Journal of Homosexuality, Vol. 41 (1), tahun 2001.

Kugle, Scott Siraj al-Haqq. Homosexuality in Islam: Critical Reflection on Gay, Lesbian, and Transgender Muslims, Oxford: One World Publications, 2010.

Martono, Nanang. Sosiologi Pendidikan Michel Foucalt: Pengetahuan, Kekuasaan, Disiplin, Hukuman dan Seksualitas, Depok: RajaGrafindo Persada, 2014. 
Mulia, Musdah. Islam dan Hak Asasi Manusia; Konsep dan Implementasi, t.t., Naufan Pustaka, 2010

Mustaqim, Abdul. "Homoseksual Dalam Perspektif Alquran: Pendekatan Tafsir Kontekstual al-Maqashidi”, SUHUF: Jurnal Kemenag, Vol. 9, No. 1, Juni 2016.

Nietzell, dkk. Abnormal Psychology, Boston: Allyn \& Bacon, Inc.), 1998.

Oetomo, Dede. Memberi Suara Pada Yang Bisu. Yogyakarta: Galang Pres, 2001.

P. C., Kendall. Abnormal Psychology Human Problems Understanding Second Editions, Boston: Houghton Mifflin Company, 1998.

Pranata, Tommy Dwi. "Perilaku dan Realitas Sosial Kehidupan Gay di Kota Samarinda”, e-Journal Sosiatri-Sosiologi, Vol. 3, 2015.

Rakhmahappin, Yogestri. "Kecemasan Sosial Kaum Homoseksual Gay dan Lesbian", Jurnal Ilmiah Psikologi Terapan, Vol. II, Januari 2014.

Saeed, Abdullah. Interpreting the Quran: Towards a Contemporary Approach. terj. Lien Iffah Naf'atu Fina, Yogyakarta: Baitul Hikmah Press, 2015.

www.africabib.org

www.almaany.com

www.olfa-youssef.prog

Yacoub, Mohamed. "Mooting Homosexuality in Islam". Diakses tanggal 3 September 2017. https://www.researchgate.net/ publication $/ 311735563$.

Youssef, Olfa. Hayrotu Muslimah: fi al-Mi>rats wa al-Zawa>j wa al-Jinsiyyah al-Mithliyyah, Cet. III. Tunisia: Dar al-Sihr li alNasyr, 2008. 